\title{
Expression of Lily mottle virus Coat Protein and Preparation of IgY Antibody against the Recombinant Coat Protein
}

\author{
Ha Na Yoo and Yong-Tae Jung* \\ Department of Microbiology, Dankook University, Cheonan 330-714, Korea
}

\begin{abstract}
Lily symptomless virus (LSV), Lily mottle virus (LMoV), and Cucumber mosaic virus (CMV) are the most prevalent viruses infecting lilies in Korea. Leaf and bulb samples showing characteristic symptoms of virus infection were collected in 2012, and 80 field samples were analyzed by reverse transcription polymerase chain reaction (RT-PCR). The infection frequencies were $79 \%$ for $\mathrm{LMoV}, 5 \%$ for $\mathrm{LSV}$, and 3\% for CMV. The LMoV coat protein gene was amplified and cloned into the pET21d(+) expression vector to develop serological diagnostic tools to detect LMoV. The resulting carboxy-terminal His-tagged coat proteins were expressed in Escherichia coli strain BL21 (DE3) by induction with IPTG. The recombinant proteins were purified using Ni-NTA agarose beads and used as an antigen to produce polyclonal antibodies in laying hens. The resulting egg yolk immunoglobulin (IgY) specifically recognized LMoV from infected plant tissues in immunoblotting assays and had comparable sensitivity to that of a mammalian antibody. In addition, method of immunocapture RT-PCR using this IgY was developed for sensitive, efficient, and rapid detection of LMoV. Based on these results, large-scale bulb tests and detection of LMoV in epidemiological studies can be performed routinely using this IgY. This is the first report of production of a polyclonal IgY against a plant virus and its use for diagnosis.
\end{abstract}

Additional key words: egg yolk immunoglobulin, IC-RT-PCR

\section{Introduction}

Lily symptomless virus (LSV), Lily mottle virus (LMoV), and Cucumber mosaic virus (CMV) are found in Korea. $\mathrm{LMoV}$ is widespread, whereas little spread of CMV has been reported (Lim et al., 2009). These viruses occur in the field as single or mixed infections within lily plants. The symptoms of lily viruses vary from vein clearing, leaf mottling, leaf mosaicism, chlorosis and yellow streaking, leaf curling, and brownish-necrotic spots to milder leaf symptoms. The development of mild symptoms in many cultivars prevents efficient removal of diseased plants, which may lead to an unacceptably high incidence of viruses in bulbs (Asjes, 2000). LMoV is a member of the Potyvirus genus within the Potyviridae family that has a linear single strand-positive sense-strand RNA genome of $9.6 \mathrm{~kb}$ containing a single large predicted open reading frame (Zheng et al.,
2003). Symptoms of LMoV range from fairly mild to severe compared to those of LSV, which range from symptomless to mild. If LMoV-infected plants are also infected with LSV, symptoms can be more severe.

Conventional reverse transcription polymerase chain reaction (RT-PCR), real-time RT-PCR and enzyme-linked immunosorbent assays (ELISA) have been developed to detect lily viruses in infected leaves and bulbs. In earlier studies, RT-PCR was used to identify and detect lily viruses (Ha et al., 2008; Lim et al., 2009). Real-time RT-PCR has been used to detect and quantify plant viruses (Beuve et al., 2007; Boonham et al., 2009; Lim et al., 2010; MortimerJones et al., 2009). Among these detection methods, ELISA is cost effective and suitable for rapid detection of a large number of samples. Various ELISA alternatives based on polyclonal or monoclonal antibodies have been used widely to improve detection limits and broaden strain specificity

\footnotetext{
*Comesponding author: yjung@dankook.ac.kr

※ Received 22 October 2013; Revised 20 March 2014; Accepted 2 April 2014. This study was supported by the Center for Research and Development of Lilium, Ministry for Food, Agriculture, Forestry, and Fisheries, Republic of Korea.

(C) 2014 Korean Society for Horticultural Science
} 
(Kong et al., 2009; Wang et al., 2010; Wu et al., 2011; Zein et al., 2007). High viral concentrations can be detected by ELISA, but it is not as useful for detecting low viral concentrations (Kim et al., 1995, 2012; Niimi et al., 1999). Preparation of a good quality antibody is important to achieve a highly sensitive ELISA, but large-scale production of mammalian antibodies is expensive and difficult.

Chicken egg yolk immunoglobulin (IgY) production has several advantages over conventional mammalian antibody production; chickens produce larger amounts of antibodies, IgY isolation is fast and simple, and egg collection is noninvasive (Dias et al., 2010; Schade et al., 2005; Spillner et al., 2012). IgY is the major antibody produced by laying hens. After immunization, IgY is secreted into the blood and transported to the egg yolk. Three immunoglobulins (IgM, IgA, and IgY) have been identified in chickens. IgM and IgA are undetectable in egg yolk, but IgY concentrations are $50-100 \mathrm{mg} / \mathrm{egg}$ yolk. One hen can produce 20 eggs per month and it is possible to obtain $>20 \mathrm{~g} \mathrm{IgY/year,}$ as hens continually produce eggs for at least 10 months. The use of IgY may help lower costs of immunological testing. IgY has been used in several studies for diagnostics and therapy (Dai et al., 2013; Wen et al., 2012).

In this study, we determined whether IgY could recognize the coat protein (CP) present in leaves. LMoV CP was expressed in Escherichia coli using the pET-21d(+) expression system and then used as an immunogen for producing chicken egg yolk IgY. IgY functioned well in Western blot analyses and immunocapture RT-PCR (IC-RT-PCR).

\section{Materials and Methods}

\section{Collection of Field Samples}

Leaf and bulb samples with characteristic symptoms of lily virus infection were collected in different regions of Korea in 2012. Samples known to be infected with LMoV were obtained from the National Institute of Horticultural
\& Herbal Science (Suwon, Korea) and stored at $-80^{\circ} \mathrm{C}$ for use as positive controls.

\section{Conventional RT-PCR}

Infected leaves and bulbs were ground to a fine powder in liquid nitrogen using a mortar and pestle. Total RNA was extracted using Trizol reagent (Invitrogen, Carlsbad, CA, USA). Primers for specific detection of LSV, LMoV, and CMV were designed based on the alignment of the CP sequence of each pathogen available in the GenBank database (Table 1). RT and subsequent PCR reactions were conducted using a MJ Research PTC-150 Thermal Cycler (PE Applied Biosystems, Foster City, CA, USA) with the Maxime RT-PCR PreMix kit (Intron Biotechnology, Daejeon, Korea). The thermal cycling scheme was $42^{\circ} \mathrm{C}$ for $45 \mathrm{~min}$, followed by 30 cycles of $95^{\circ} \mathrm{C}$ for $30 \mathrm{sec}, 50^{\circ} \mathrm{C}$ for $1 \mathrm{~min}$, and $72^{\circ} \mathrm{C}$ for $30 \mathrm{sec}$, with a final extension at $72^{\circ} \mathrm{C}$ for $7 \mathrm{~min}$. The PCR products were examined by electrophoresis on $1.5 \%$ agarose gels. RT-PCR products were cloned into the pGEM-T Easy plasmid vector (Promega, Madison, WI, USA) to construct the recombinant plasmids.

\section{Cloning and Prokaryotic Expression of the CP Gene}

The LMoV CP1 forward primer (5'-CCATGGCAAATGAGA CACTTAAC-3', NcoI restriction site is underlined), and the LMoV CP2 reverse primer (5'-CTCGAGCATAGAAATTCCAA GTAA-3', XhoI restriction site is underlined) were used to amplify the LMoV CP gene. The RT-PCR products were cloned into a pGEM-T Easy plasmid vector (Promega). The target fragment was released from the cloned pGEM-T Easy plasmid using $\mathrm{Ncol} / \mathrm{XhoI}$ and inserted into the corresponding sites of the pET21d $(+)$ expression vector (Novagen, Gibbstown, NJ, USA). The recombinant plasmid was transformed in E. coli strain BL21 (DE3). Protein expression was induced at an absorbance of 0.3 at $600 \mathrm{~nm}$ using isopropyl-1-thio- $\beta$ -D-galactoside (IPTG) in a final concentration of $1 \mathrm{mM}$, and the culture was incubated for $5 \mathrm{~h}$ with shaking at $37^{\circ} \mathrm{C}$.

Table 1. PCR primers for the detection of Lily viruses from infected leaves.

\begin{tabular}{lllc}
\hline Viruses & Pimer & \multicolumn{1}{c}{ Sequence $\left(5^{\prime}-3^{\prime}\right)$} & Product size $(\mathrm{bp})$ \\
\hline LSV & LSV-F & 5'-CACATATGCAATCAAGACCAGCAC-3' & 890 \\
& LSV-R & 5'-GAGGATCCTCATCCATTATTTGCGTATC-3' & \\
LmoV & LMoV-F & 5'-GCAAATGAGACACTCAATGCTG-3' & 651 \\
& LMoV-R & 5'-CGTGCGTGAAGTAACTTCATAG-3' & \\
CMV & CMV-F & 5'-CTCATGGATGCTTCTCCGC-3' & 904 \\
& CMV-R & 5'-ACTGACCATTTTAGCCGTAA -3' & \\
\hline
\end{tabular}


The supernatant containing 6X His-fused CP was purified using Ni-NTA agarose beads (Qiagen, Hilden, Germany). The purified protein solution was quantified by standardization with bovine serum albumin and estimated by its molar extinction coefficient at $595 \mathrm{~nm}$.

\section{Immunization of Chickens}

The purified recombinant $\mathrm{CP}$ was used as an immunogen and injected into 28-week-old ISA-brown chickens. Chickens were immunized on weeks 0,2 , and 4 . The antigen was emulsified with an equal volume of Freund's complete adjuvant (Sigma-Aldrich, St. Louis, MO, USA) for the first immunization. Freund's incomplete adjuvant was similarly used for subsequent boosting immunizations. Eggs were collected 28 days from the initial immunization

\section{Western Blot Analysis}

Leaf samples from healthy or virus-infected plants were homogenized in sodium dodecyl sulfate (SDS) extraction buffer. The samples were denatured by boiling for $3 \mathrm{~min}$ and then separated on $12 \%$ SDS-polyacrylamide gel electrophoresis (SDS-PAGE) gels. The proteins were then transferred to nitrocellulose membranes. The membranes were blocked in Tris-buffered saline Tween-20 (TBS-T) buffer containing $5 \%$ skim milk powder at $4^{\circ} \mathrm{C}$ overnight and incubated with primary polyclonal antibodies (IgG and IgY) specific to $\mathrm{LMoV}$ at room temperature for $2 \mathrm{~h}$. After three washes in TBS-T, the membranes were incubated with horseradish peroxidase-conjugated goat anti-rabbit IgG (KOMAbiotech, Seoul, Korea) or mammalian antibody and AP-conjugated rabbit anti-chicken IgY $(1: 10,000)$ (Bethyl Laboratories, Montgomery, TX, USA) at room temperature for $1 \mathrm{~h}$.

\section{IC-RT-PCR}

Leaf samples from lily plants showing disease symptoms were collected, and sap was extracted from the leaf samples using extraction buffer. The sap was centrifuged at 13,000 rpm for $1 \mathrm{~min}$ and the supernatants were kept on ice. A $200 \mu \mathrm{L}$ aliquot of each diluted primary polyclonal antibody (IgG and IgY) was added to PCR tubes and incubated at $37^{\circ} \mathrm{C}$ for $4 \mathrm{~h}$. After three washes in TBS-T, $200 \mu \mathrm{L}$ of leaf sap was dispensed into the PCR tubes and incubated overnight at $4^{\circ} \mathrm{C}$. After three washes in TBS-T, the virions were disrupted at $80^{\circ} \mathrm{C}$ for $10 \mathrm{~min}$ and used for RT-PCR. The LMoV forward primer (5'-GCGTTCCAGGCAAATGAG-3'), and the LMoV reverse primer (5'-GTAAACCACACTATAACA CAAAGAG-3') were used to amplify the LMoV gene.

\section{Results}

\section{Conventional RT-PCR Assay}

Leaf samples and bulbs showing characteristic symptoms of virus infection were collected from Gang-won and Chungnam province, Korea in 2012. LSV, LMoV, and CMV were detected by RT-PCR (Fig. 1). Eighty field samples showing characteristic symptoms of virus infection were identified; four plants with LSV, 63 plants with LMoV, and two plants with CMV. LMoV predominated in our tests, whereas little spread of LSV and CMV was found. The nucleotide sequences of eight isolates were identified (six LMoV; GenBank accession numbers KC430329 to KCKC430332, KC243417, JX908883: one LSV; JX962776: one CMV, JX913865). The CP regions were determined and compared with the corresponding regions of LMoV (AJ564636), LSV (AJ516059), and CMV (AJ296154). The nucleic acid identities between reference viruses and eight isolates were 95-99\%.

\section{Cloning and Expression of $\mathrm{LMoV} \mathrm{CP}$}

The entire LMoV $c p$ gene was cloned from genomic RNA

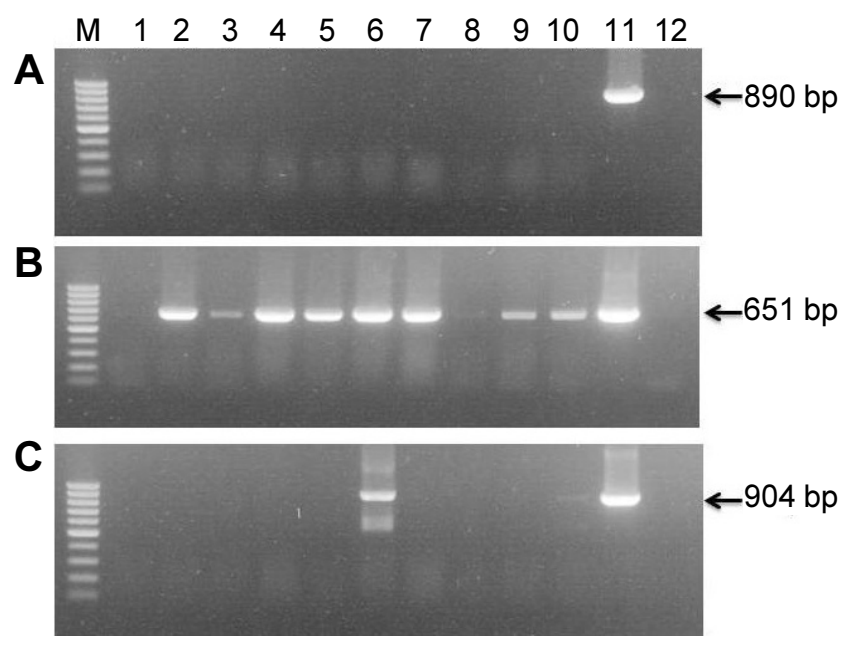

Fig. 1. Reverse transcription polymerase chain reaction (RTPCR)-based detection of Lily symptomless virus (LSV: A), Lily mottle virus (LMoV: B), and Cucumber mosaic virus (CMV: C) in lily plants. Leaf samples with characteristic symptoms of lily virus infection were collected in different regions of Korea in 2012. The lengths of the PCR products were 890 bp (A), 651 bp (B), and 904 bp (C), respectively. Lane M, molecular size markers (100 bp ladder, Fermentas, Pittsburgh, PA, USA); lane 1, extract from healthy lily plant ('Sorbonne'); lanes 2-10, extracts from a diseased lily plant (lanes 2, 3, and 7 'Sorbonne'; lanes 4-6 'Ivory'; lane 8 'Yelloween'; lanes 9 and 10 'Siberia'); lane 11, cloned plasmid as a positive control; lane 12, water as a negative control. 
extracted from virus-infected lily by RT-PCR, and the sequence was confirmed using an automated DNA sequencing system. The amplified fragments were inserted between the $\mathrm{NcoI}$ and $X$ hoI sites in pET-21d(+) to produce a C-terminal His-tagged CP fusion protein. The resulting plasmid was designated pET-21d(+)-LMoV-CP. SDS-PAGE revealed that the recombinant LMoV CP band with a molecular mass of $30 \mathrm{kDa}$ was expressed successfully in IPTG-induced pET-21d(+)-LMoV-CP(-)-transformed bacteria but not in pET-21d(+)-transformed control bacteria. Recombinant His-tagged LMoV-CP was purified from the soluble bacteria fractions through an Ni-NTA agarose column by elution with $300 \mathrm{mM}$ imidazole buffer. The eluted fraction contained a major band of the $30 \mathrm{kDa}$ recombinant $\mathrm{CP}$ and was used to induce production of polyclonal antiserum in rabbit and chicken (Fig. 2).

\section{Detection of LMoV by Western Blot Using PAbs}

To evaluate the suitability of PAbs to LMoV, antibodies recovered from rabbit and chicken were diluted to 1:10,000 for Western blotting. Figure 3 shows that both the IgY and IgG antibody reacted with LMoV-infected plant tissue extracts and the recombinant His-LMoV CP but not with healthy samples. IgY produced slightly stronger signals than those of IgG. Although some samples (Fig. 3, lanes 2 and 3) were RT-PCR positive, the CP band was not visible

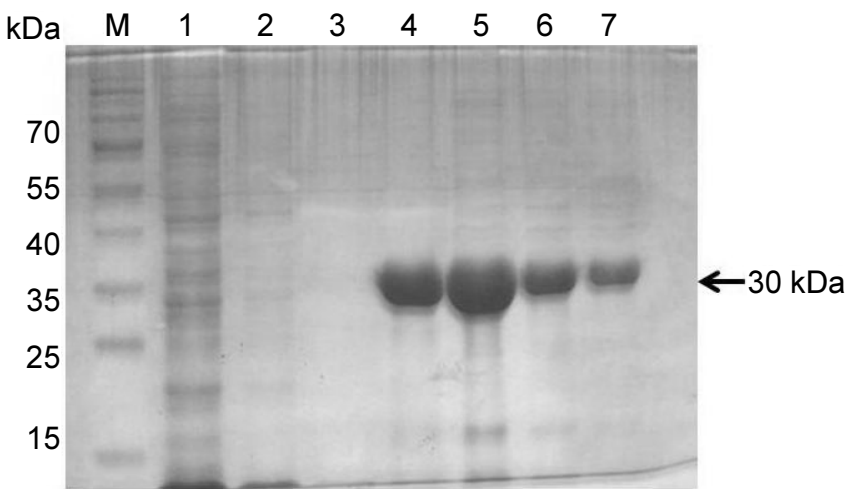

Fig. 2. Purification of recombinant His-coated Lily mottle virus (LMoV) coat protein (CP) after Ni-NTA affinity chromatography. The LMoV CP gene was cloned into pET21d(+) expression vector and the recombinant plasmid was transformed in E. coli strain BL21(DE3). Protein expression was induced at an absorbance of 0.3 at $600 \mathrm{~nm}$ using IPTG in a final concentration of $1 \mathrm{mM}$, and the culture was incubated for $5 \mathrm{~h}$ with shaking at $37^{\circ} \mathrm{C}$. The supernatant containing $6 \mathrm{X}$ His-fused CP was purified using Ni-NTA agarose beads. Lane $\mathrm{M}$, protein ladder; lane 1, flow-through; lanes 2-3, column washing; lanes 4-6, elution of recombinant CP from the column in the Western blot.

\section{IC-RT-PCR for Detecting LMoV}

The IC-RT-PCR method was used to test for the presence of LMoV in field samples. PAb (100 $\mu \mathrm{L})$ diluted at 1:100 in coating buffer was used to coat the PCR tubes, and $100 \mu \mathrm{L}$ of leaf sap was used for detection. LMoV primers produced a single $935 \mathrm{bp}$ band from LMoV-infected lily plants, but no band from healthy lily samples was amplified by IC-RT-PCR. In our Western blotting experiments, some samples were not detected with either the IgY or IgG antibody, but the same samples were amplified by IC-RT-PCR.

\section{Discussion}

LMoV is widespread in Korea and causes serious yield losses in lily plants. Therefore a simple, reliable, and sensitive technique to control the viral disease is required. Real-time RT-PCR has been used to rapidly detect LMoV, but this method is not suitable for large numbers of samples (Lim

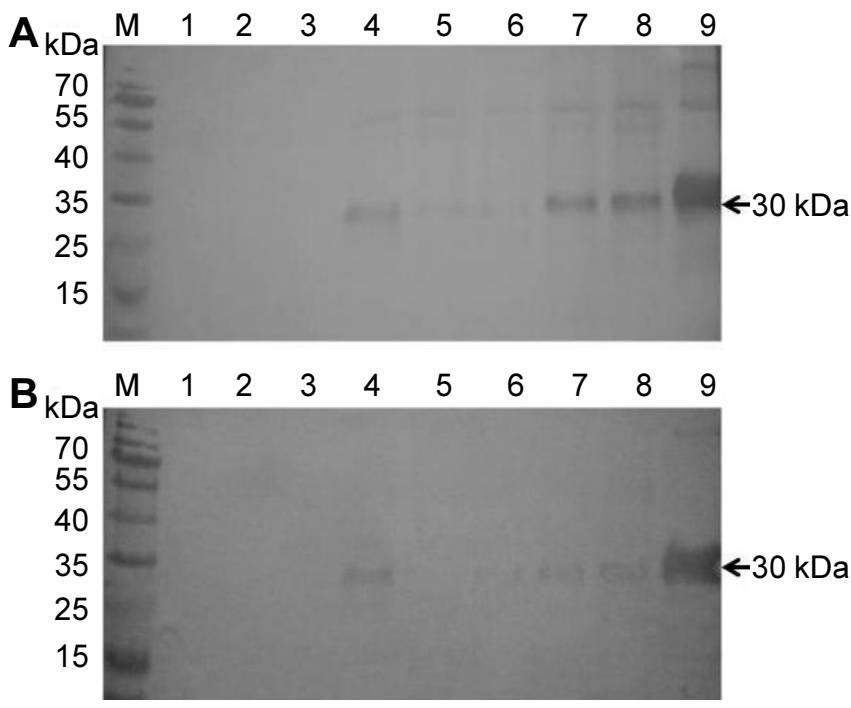

Fig. 3. Western blot detection of the Lily mottle virus (LMoV) coat protein in healthy and infected lily samples using IgY (A) and IgG (B) antibodies. The proteins were transferred to nitrocellulose membranes and the membranes were incubated with primary polyclonal antibodies (IgY and IgG) specific to $\mathrm{LMoV}$. After washes, the membranes were incubated with AP-conjugated rabbit anti-chicken $\operatorname{IgY}(\mathrm{A})$ and horseradish peroxidase-conjugated goat anti-rabbit IgG(B). Lane M, protein marker; lane 1, extract from healthy lily plant as negative control; lanes 2-8 (lane 2, 'Le Reve'; lane 3, 'Siberia'; lanes 4-7, 'Medusa'; lane 8, unknown) extracts from a diseased lily plant; lane 9, purified His-tag coat protein of LMoV as positive control. 
et al., 2010). ELISA with PAbs or monoclonal antibodies is more convenient and practical than real-time RT-PCR (Edwards and Cooper, 1985; Liebenberg et al., 2009; Tatineni et al., 2013). However, it is not easy to diagnose mixed infections with ELISA and it is not as useful for detecting low viral concentrations. In addition, preparation of a good qualitative and highly specific antibody is critical for obtaining reliable results.

In this study, the nucleic acid homologies between the different $\mathrm{LMoV}$ isolates were 95-99\% and such high sequence conservation allows LMoV CP to be a suitable immunogen to produce IgY for detecting different $\mathrm{LMoV}$ isolates. The conventional method of antigen preparation is virion purification following virus propagation but $\mathrm{LMoV}$ is difficult to purify due to its fragility and uneven distribution. In addition, lilies are often infected simultaneously by two or three different viruses. Using recombinant CP expression in a prokaryotic system does not cause these problems because it is simple, fast, and economical. Specific antiserum prepared using recombinant $\mathrm{CP}$ and its application to serological diagnostic tests has been successfully demonstrated for a number of plant viruses (Gulati-Sakhuja et al., 2009; Kim et al., 2012; Wu et al., 2013).

IgY, the predominant serum immunoglobulin in birds, reptiles, and amphibians, is transferred from serum to egg yolk to confer passive immunity to embryos and baby chicks. In recent years, specific IgY has received considerable attention in passive immunotherapy for infectious disease due to a number of advantages (Dai et al., 2013; Wen et al., 2012). IgY can be extracted in high yield and recovered from immunized hens over prolonged periods. The phylogenic distance of birds from mammals makes production of antibodies against antigens that may be non-immunogenic in mammals more successful in chickens. In addition, IgY binds neither the mammalian Fc receptor nor the rheumatoid factor. These differences have allowed for increasing interest in a wide variety of applications such as xenotransplantation, immunodiagnostics, and immunotherapy. Compared to antibody production in rabbits, IgY technology is economic, and very low quantities of antigen are required to obtain long-lasting and high IgY titers (Dias et al., 2010; Schade et al., 2005; Spillner et al., 2012).

In this study, the LMoV CP was expressed in E. coli, and two PAbs were produced in rabbits and chickens. A single protein band with a molecular mass close to $\mathrm{LMoV}$ was specifically detected by Western blotting in virus-infected leaf samples, although the CP bands were not detected in some leaf samples (Fig. 3). These findings indicate that the PAbs prepared in this study were highly specific for
LMoV and IgY and that they have comparable sensitivity to a mammalian antibody. We also developed an IC-RT-PCR procedure that offers sensitive, specific, and rapid detection of LMoV in field samples. This method avoided RNA extraction and was carried out easily in a single tube. IC-RT-PCR methods have been developed for detecting many other plant viruses (Ganesh Selvaraj et al., 2009; Kim et al., 2012; Wu et al., 2011). We found that a single 935-bp band could be amplified from LMoV-infected leaf sap using the IC-RT-PCR assay, whereas no DNA band was amplified from healthy leaf sap (Fig. 4). IgY against CP has been used successfully to detect LMoV infection by IC-RT-PCR. In addition, IC-RT-PCR detected viruses in lily samples that were negative by Western blot. We speculate that a low virus concentration in some samples may have caused detection problems.

In conclusion, we successfully produced a large amount of IgY against LMoV by immunizing laying hens with recombinant $\mathrm{LMoV} \mathrm{CP}$. Using this PAb, IC-RT-PCR was established for detecting lily viruses in field samples. This method can be used for virus surveillance to help reduce economic losses in the lily industry. Our results suggest that IgY may offer a new large-scale source of low-cost antibodies.

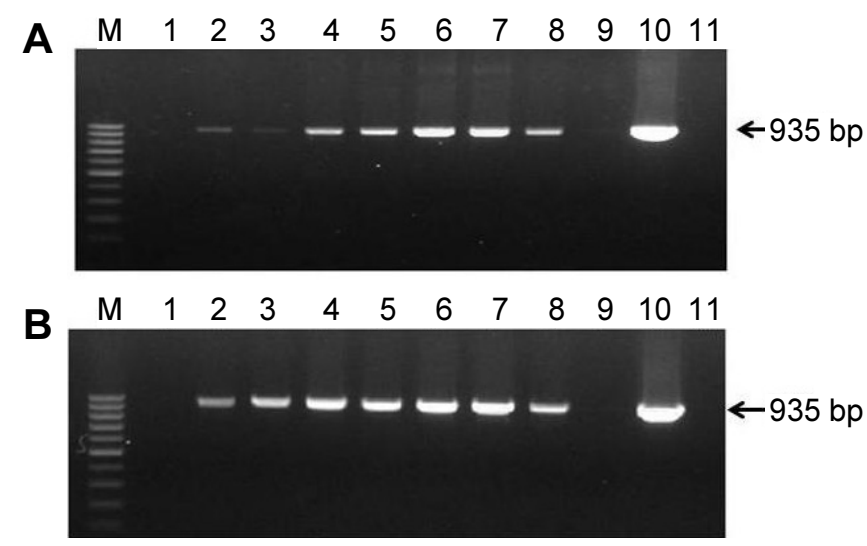

Fig. 4. Immunocapture-reverse transcription polymerase chain reaction (IC-RT-PCR) detection of the Lily mottle virus (LMoV) coat protein in healthy and infected lily samples using IgY (A) and IgG (B) antibodies. A aliquot of each diluted primary polyclonal antibody (IgG and IgY) was added to PCR tubes. After washes, leaf sap was dispensed into the PCR tubes. The virions were disrupted and used for RT-PCR. Lane M, Molecular size markers (100 bp ladder, Fermentas, Pittsburgh, PA, USA); lanes 1 and 9, extract from a healthy lily plant; lanes 2-8 (lane 2, 'Le Reve'; lane 3, 'Siberia'; lanes 4-7, 'Medusa'; lane 8, unknown), extracts from a diseased lily plant; lane 10, PCR positive control; lane 11, PCR negative control. 


\section{Literature Cited}

Asjes, C.J. 2000. Control of aphid-borne Lily symptomless virus and Lily mottle virus in Lilium in the Netherlands. Virus Res. 71:23-32.

Berniak, H., T. Malinowski, and M. Kaminska. 2010. Characterization of polyclonal antibodies raised against two isolates of Cucumber mosaic virus. J. Plant Pathol. 92:231-234.

Beuve, M., L. Sempé, and O. Lemaire. 2007. A sensitive one-step real-time RT-PCR method for detecting Grapevine leafrollassociated virus 2 variants in grapevine. J. Virol. Methods 141:117-124.

Boonham, N., L. Laurenson, R. Weekes, and R. Mumford. 2009. Direct detection of plant viruses in potato tubers using real-time PCR. Methods Mol. Biol. 508:249-258.

Dai, Y.C., X.F. Zhang, M. Tan, P. Huang, W. Lei, H. Fang, W. Zhong, and X. Jiang. 2013. A dual chicken IgY against rotavirus and norovirus. Antiviral Res. 97:293-300.

Dias da Silva, W. and D.V. Tambourgi. 2010. IgY: A promising antibody for use in immunodiagnostic and in immunotherapy. Vet. Immunol. Immunopathol. 135:173-180.

Edwards, M.L. and J.I. Cooper. 1985. Plant virus detection using a new form of indirect ELISA. J. Virol. Methods 11:309-319.

Ganesh Selvaraj, D., R. Pokorný, and L. Holková. 2009. Comparative analysis of ELISA, one step RT-PCR and IC-RT-PCR for the detection of bean yellow Mosaic virus in gladiolus. Commun. Agric. Appl. Biol. Sci. 74:853-859.

Gulati-Sakhuja, A., J.L. Sears, A. Nuñez, and H.Y. Liu. 2009. Production of polyclonal antibodies against Pelargonium zonate spot virus coat protein expressed in Escherichia coli and application for immunodiagnosis. J. Virol. Methods 160:29-37.

Ha, C., S. Coombs, P.A. Revill, R.M. Harding, M. Vu, and J.L. Dale. 2008. Design and application of two novel degenerate primer pairs for the detection and complete genomic characterization of potyviruses. Arch. Virol. 153:25-36.

Kim, J.H., H.N. Yoo, E.H. Bae, and Y.T. Jung. 2012. Development of an indirect ELISA and immunocapture RT-PCR for Lily virus detection. J. Microbiol. Biotechnol. 22:1776-1781.

Kim, J.Y., S.T. Choi, and H.T. Hsu. 1995. Comparision of detection efficiency of lily symptomless virus in lily bulbs by ELISA, DBIA and tissue blotting method. J. Kor. Soc. Hort. Sci. 36:560-566.

Kong, B., J. Yu, H. Chen, D. Li, C. Han, and J. Wang. 2009. Production of antiserum to recombinant coat protein for detecting Lily mottle virus in Yunnan, China. J. Phytopathol. 157:362-369.

Liebenberg, A., M.J. Freeborough, C.J. Visser, D.U. Bellstedt, and J.T. Burger. 2009. Genetic variability within the coat protein gene of Grapevine fanleaf virus isolates from South Africa and the evaluation of RT-PCR, DAS-ELISA and ImmunoStrips as virus diagnostic assays. Virus Res. 142:28-35.

Lim, J.H., E.H. Bae, Y.J. Lee, S.H. Park, K.J. Lee, S.R.M. Kim, and Y.T. Jung. 2009. Detection of Lily symptomless virus, Lily mottle virus and Cucumber mosaic virus from Lilium grown in Korea by RT-PCR. Kor. J. Microbiol. 45:251-256.

Lim, J.H., E.H. Bae, S.H. Park, K.J. Lee, S.R.M. Kim, E.Y. Kwon, Y.J. Lee, and Y.T. Jung. 2010. Development of a real time RT-PCR with SYBR Green dye for the detection of several viruses from the bulbs and leaves of lily. Acta Virol. 54:319-321.

Mortimer-Jones, S.M., M.G. Jones, R.A. Jones, G. Thomson, and G.I. Dwyer. 2009. A single tube, quantitative real-time RT-PCR assay that detects four potato viruses simultaneously. J. Virol. Methods 161:289-296.

Niimi, Y., T. Gondaira, Y. Kutsuwada, and H. Tsuji. 1999. Detection by ELISA and DIBa tests of Lily symptomless virus (LSV), Tulip breaking virus-lily (TBV-L) and Cucumber mosaic virus (CMV) in Lilium spp. grown in the field. J. Japan. Soc. Hort. Sci. 68:176-183.

Schade, R., E.G. Calzado, R. Sarmiento, P.A. Chacana, J. PorankiewiczAsplund, and H.R. Terzolo. 2005. Chicken egg yolk antibodies (IgY-technology): A review of progress in production and use in research and human and veterinary medicine. Altern. Lab. Anim. 33:129-154.

Spillner, E., I. Braren, K. Greunke, H. Seismann, S. Blank, and D. du Plessis. 2012. Avian IgY antibodies and their recombinant equivalents in research, diagnostics and therapy. Biologicals. 40:313-322.

Tatineni, S., G. Sarath, D. Seifers, and R. French. 2013. Immunodetection of Triticum mosaic virus by DAS- and DAC-ELISA using antibodies produced against coat protein expressed in Escherichia coli: Potential for high-throughput diagnostic methods. J. Virol. Methods. 189:196-203.

Wang, R., G. Wang, Q. Zhao, Y. Zhang, L. An, and Y. Wang. 2010. Expression, purification and characterization of the Lily symptomless virus coat protein from Lanzhou Isolate. Virol. J. 34:1-7.

Wen, J., S. Zhao, D. He, Y. Yang, Y. Li, and S. Zhu. 2012. Preparation and characterization of egg yolk immunoglobulin $\mathrm{Y}$ specific to influenza B virus. Antiviral Res. 93:154-159.

Wu, J., C. Meng, H. Shang, S. Rong, C. Zhang, J. Hong, and X. Zhou. 2011. Monoclonal antibody-based triple antibody sandwich-enzyme-linked immunosorbent assay and immunocapture reverse transcription-polymerase chain reaction for Odontoglossum ringspot virus detection. J. Virol. Methods 171:40-45.

Wu, J., Y. Ni, H. Liu, L. Rao, Y. Zhou, and X. Zhou. 2013. Development and use of three monoclonal antibodies for the detection of rice black-streaked dwarf virus in field plants and planthopper vectors. Virol. J. 10:114.

Zein, H.S., M. Nakazawa, M. Ueda, and K. Miyatake. 2007. Development of serological procedures for rapid and reliable detection of Cucumber mosaic virus with dot-immunobinding assay. World J. Agric. Sci. 3:430-439.

Zheng, H.Y., J. Chen, M.F. Zhao, L. Lin, J.P. Chen, J.F. Antoniw, and M.J. Adams. 2003. Occurrence and sequences of Lily mottle virus and Lily symptomless virus in plants grown from imported bulbs in Zhejiang province, China. Arch. Virol. 148:2419-2428. 